\title{
Studies on Schismatoglottideae (Araceae) of Borneo LXIII: Three New Species for the Schismatoglottis Patentinervia Clade
}

\author{
PETER C. BOYCE \\ Ludwig-Maximilians-Universitat Munchen, Department Biologie I, Systematische Botanik und \\ Mykologie, Menzinger Strase 67, 80638 Munchen, Germany \\ Corresponding author: boyce@ biologie.uni-muenchen.de
}

\begin{abstract}
Three new species of the Schismatoglottis Patentinervia Clade are described and illustrated from Sarawak, Malaysian Borneo, and included in an updated identification key to the described species in clade. Two of the novelties are from Serian Division, SW Sarawak: Schismatoglottis pichinensis P.C. Boyce sp. nov., restricted to forested limestone at low altitudes, and S. puncakborneensis P.C. Boyce sp. nov., occurring in moist upper hill forest on Paleogene sandstones. The third, S. gephyra P.C. Boyce sp. nov., is a lowland species from NE Borneo on Oligocene sedimentaries. Recognition of these three species takes the Patentinervia Clade to nine described species, of which seven have only been formally recognized since 2000.
\end{abstract}

Keywords: Borneo, Sarawak, aroids, taxonomy

\section{INTRODUCTION}

The Schismatoglottis Patentinervia Clade (Low, 2016; Low et al., in press; Wong et al., 2017) is a monophyletic taxon of six described species of small mesophytic herbs defined by erect to decumbent epigeal stems composed of pleionanthic modules (an exception seemingly being $S$. pectinervia A. Hay - Figure 4E), with older portions of at least some species producing hapaxanthic reiterations from older portions of the stems. Leaf blades are lanceolate to oblongelliptic to narrowly obovate, lack posterior lobes, and have numerous rather closely spaced primary lateral veins diverging from the mid-rib at about $90^{\circ}$ and running more or less straight for much of the width of the blade before rather abruptly arching upwards to merge into one or two intramarginal veins, secondary venation mostly arising from the midrib and running parallel to the primary lateral veins, and tertiary venation abaxially forming a more or less obscure tessellate reticulum. Blades are often markedly discolorous with the abaxial surface notably paler than the adaxial. A few species are able to propagate vegetatively from leaf blades, a trait shared with some species of the related Nervosa Grade (Wong et al., 2016). The petiolar sheath is fully attached, membranous and longpersistent and typically occupies more than half the length of the petiole. Inflorescences are solitary, seldom paired, and erect on a short peduncle concealed by leaf bases. The spathe limb opens only slightly at anthesis and characteristically darkens and rots (although not deliquescing) during late staminate anthesis, while the lower spathe has remarkably thickened walls which in some species become semitransparent during anthesis. The spadix has a pronounced appendix isodiametric to slightly wider than the staminate flower zone, stamens rather vaguely arranged into bistaminate flowers, powdery pollen, a well-differentiated interstice, pistillate flowers lacking interpistillar staminodes or if present then restricted to a single zone of large rectangular staminodes at the base of the pistillate flower zone, and erect infructescences with the thick walled persistent lower spathe orifice rather wide.

The Patentinervia Clade is entirely Bornean. All known species are locally restricted and all appear to be geologically obligated, a common phenomenon for Bornean Araceae (Boyce \& Wong, 2015) and in large part explaining the extraordinary abundance of aroid diversity on Borneo. As stated in Wong et al. (2017), species of the Patentinervia Clade are largely undescribed, with almost $80 \%$ of the known species recognized only since 2000 . Here an additional three taxonomic novelties are described.

Dimensions in the descriptions are derived from fertile (i.e. mature) plants. Seedlings have overall smaller measurements.

Geological occurrences are verified using Tate (2001). 
Key to Species of the Schismatoglottis Patentinervia Clade

1. Leaf blades thin, stiff, adaxially deep lustrous metallic blue-green; innovations brilliant lime green; petioles and abaxial mid-rib minutely and densely puberulent with stiff short hairlike papillae. Kapuas Hulu, Kalimantan Barat Schismatoglottis patentinervia

- Leaf blades not stiff, adaxially never metallic blue-green; innovations never brilliant lime green; petioles and abaxial mid-rib mostly glabrous; if puberulent then leaf blades never stiff ..................... 2

2. Interstice of spadix isodiametric with ends of fertile zones, completely obscured by rhomboidal staminodes; spadix appendix acute to sharp-tipped, stout curving-conic... 3

- Interstice of spadix much narrower than fertile zones, naked; interstice staminodes few, scattered, round-topped ............. 4

3. Stamens appearing coalescent (in actuality very tightly appressed); pistillate flower zone with a single row of large (c. $2 \mathrm{~mm}$ wide) white waxy staminodes at base; appendix base isodiametric with top of staminate flower zone; staminate flowers dull white. N \& C Kapit - Pelagus \& Batang Balleh

\section{Schismatoglottis belonis}

- Stamens individually well-differentiated with thecae elevated and separated from those of adjacent stamens; pistillate flower zone lacking staminodes; appendix base slightly wider than top of staminate flower zone; staminate flowers very pale salmon pink. N Kapit - Belaga \& Bakun

Schismatoglottis gephyra

4. Spadix interstice about equalling pistillate flower zone in length .............5 5

- Spadix interstice much shorter than pistillate flower zone length . . . . . . . . . . 8

5. Leaf blades very narrowly elongate-elliptic, no more than $2 \mathrm{~cm}$ wide, emerald green on both surfaces; spadix interstice with large round-topped white staminodes. N Kapit, Sarawak ...... Schismatoglottis smaragdina

- Leaf blades elliptic, up to $5 \mathrm{~cm}$ wide, discolorous, paler abaxially; spadix interstice naked or with small cream flat-topped or irregular (staminate flower-like) staminodes
6. Leaf blades abaxially pruinose; lower spathe ellipsoid at pistillate anthesis; pistils small (c. $1.5 \mathrm{~mm}$ tall), stigma narrower than ovary. Serian, Sarawak, Triassic-Jurassic Karst limestone ....... Schismatoglottis pichinensis

- Leaf blades abaxially paler but never pruinose; lower spathe globose-ovoid at pistillate anthesis; pistils large (c $2.5 \mathrm{~mm}$ tall), stigma almost equalling width of ovary ......... 7

7. Lower spathe becoming translucent during anthesis; pistils cream; interstice with a few scattered staminate-flower like staminodes. Puncak Borneo, Sarawak, about $850 \mathrm{~m}$ asl, Paleogene sandstones

Schismatoglottis puncakborneensis

- Lower spathe remaining opaque during anthesis; pistils bright green; interstice naked; petioles puberulent. Kinabalu, Sabah, above $1000 \mathrm{~m}$ asl, volcanics

Schismatoglottis retinervia

8. Spadix appendix and staminate flower zone together curving-cylindric; spathe limb opening almost flat at anthesis; petioles glabrous. Pulau Sapi, Kalimantan Utara Schismatoglottis gaesa

- Spadix appendix and staminate flower zone together stoutly ovoid; spathe limb hardly opening at anthesis. Mulu, NE Sarawak \& Brunei

Schismatoglottis pectinervia

\section{Species Descriptions}

Schismatoglottis gephyra P.C. Boyce, sp. nov. (Figures $1 \& 4 F$ ).

Diagnosis: Schismatoglottis gephyra most resembles Schismatoglottis belonis by having the interstice of the spadix isodiametric with the ends of the fertile zones and being completely obscured by rhomboidal staminodes, and an acute to sharp-tipped stout curving-conic spadix. Schismatoglottis gephyra is differentiated from $S$. belonis by the very pale pink (not dull white) stamens individually well-differentiated (vs stamens very tightly appressed) with elevated thecae separated from those of adjacent stamens, by the pistillate flower zone lacking staminodes (vs having with a single row of large (c. $2 \mathrm{~mm}$ wide) white waxy staminodes at base), and by the appendix base slightly wider than the top of the staminate flower zone (vs appendix base isodiametric with the top of the staminate flower zone). 


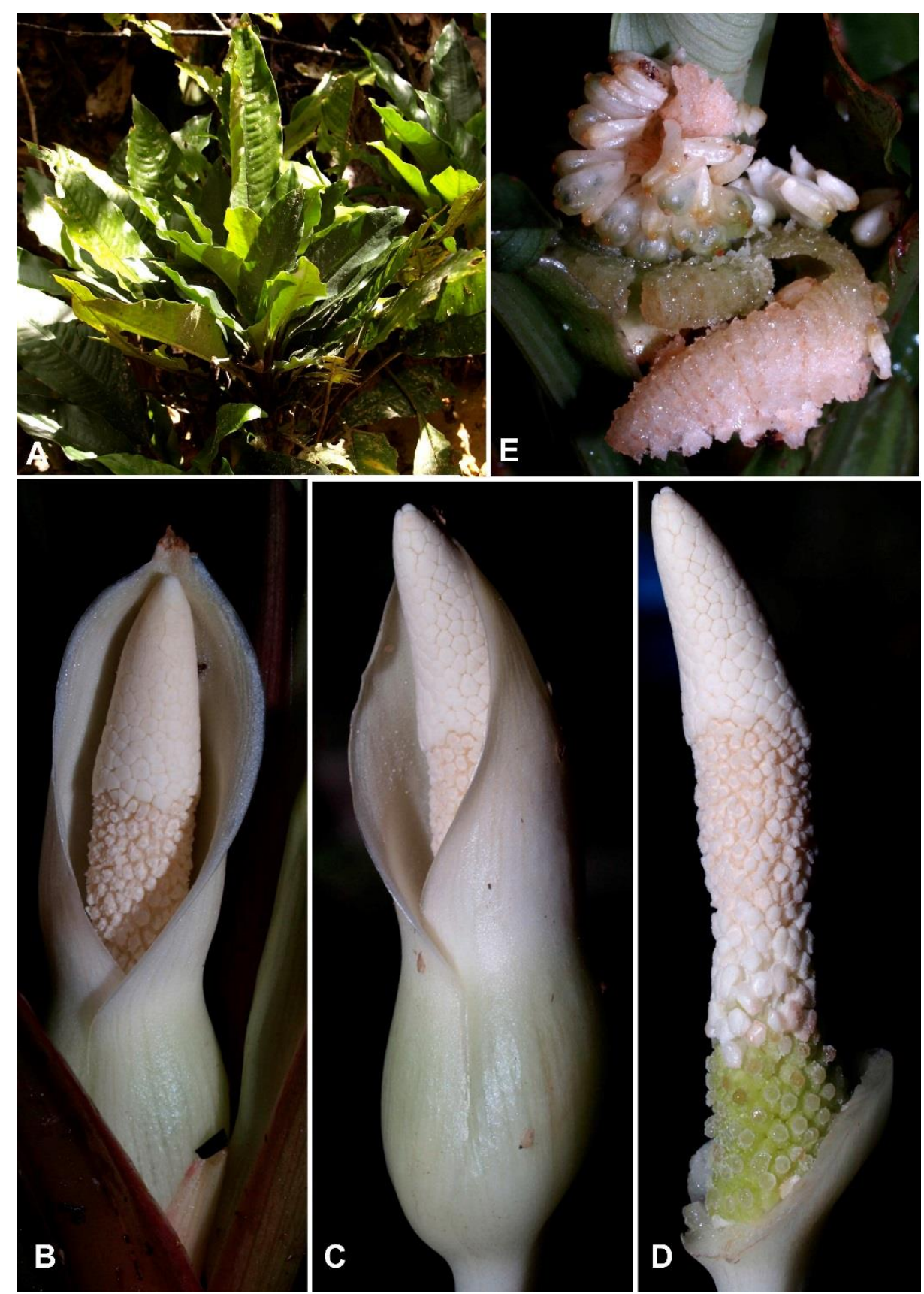

Figure 1. Schismatoglottis gephyra P.C. Boyce, sp. nov. A. Plants in habitat. B. Plant showing the pruinose abaxial surface of the leaf blades. C \& D. Inflorescence at pistillate anthesis. E. Spadix at early staminaye anthesis, spathe artificially removed. Note the powdery pollen.

Type: MALAYSIAN BORNEO. Sarawak, Kapit Division, Belaga, km 10 towards Bakun from the Bintulu-Miri road junction, 2 ${ }^{\circ} 50^{\prime} 51.7^{\prime \prime} \mathrm{N} 114^{\circ} 01^{\prime} 57.6^{\prime \prime} \mathrm{E}, 11$ Oct 2005, P.C. Boyce, Jeland ak Kisai \& Jepom ak Tisai AR1409 (Holotype: SAR; isotype SAR - alcohol preserved).

Ecology \& distribution: Lowland perhumid forest on Oligocene sedimentaries (primarily shales), between 180-245 m asl.
Description: Small clumping mesophytic herb to c. $15 \mathrm{~cm}$ tall. Stem erect, rather congested, older stems becoming decumbent with tips ascending, to c. $15 \mathrm{~cm}$ long, c. $0.7 \mathrm{~cm}$ diam., epigeal, modules pleionanthic, internodes rather abbreviated c. $1 \mathrm{~cm}$ long. Leaves several together clustered at apex od stem; petiole 6-11 cm long, sheathing in lower $1 / 2-2 / 3$, longitudinally with a few ridges, medium green, more infrequently dull reddish; petiolar sheath wings fully attached to petiole, rather unequal, one side wider and 
somewhat truncate at tip, membranous, longpersistent; leaf blades oblong-elliptic, adaxially with a slightly quilted appearance caused by the impressed veins, $7-12 \mathrm{~cm}$ long $\times 2.5-4 \mathrm{~cm}$ wide, base weakly decurrent as two brief wings, apex acute to somewhat acuminate for c. $15 \mathrm{~mm}$, glossy medium green adaxially, much paler and semi-matte abaxially; midrib abaxially prominent, adaxially slightly impressed into blade; primary lateral veins c. 20 on each side, alternating with hardly lesser interprimaries, diverging at $80-100^{\circ}$ from mid-rib, gradually up-curved more or less throughout their length to spreading then rather abruptly upcurved, impressed adaxially; secondary venation arising from midrib; tertiary venation forming a rather conspicuous tessellate reticulum abaxially. Inflorescence solitary; peduncle to c. $2.5 \mathrm{~cm}$ long, entirely obscured by leaf bases, whitish. Spathe c. $3.5 \mathrm{~cm}$ long; lower spathe $1 \mathrm{~cm}$ long, ovoid, differentiated from limb by a faint constriction, inflating at pistillate anthesis, weakly glossy very pale medium green; spathe limb broadly ovate, c. $2.5 \mathrm{~cm}$ long, acute and then briefly mucronate for c. $1.5 \mathrm{~mm}$, opening rather wide during anthesis, semi-glossy very pale greenish while green, interior paler, margins almost transparent. Spadix c. $3.5 \mathrm{~cm}$ long, sessile; pistillate flower zone c. $6 \mathrm{~mm}$ long, weakly conoid, obliquely inserted on spathe; pistils slightly congested, rather narrowly ellipsoid, $0.75 \mathrm{~mm}$ diam., bright green; stigma sessile, button-like, about as wide as ovary; interpistillar staminodes absent; sterile interstice obscured by staminodes; interstice staminodes rhomboidal-topped on a stout stipe, c. $0.5 \mathrm{~mm}$ long, glossy white; staminate flower zone rather obconoid, 6-8 mm long, $2.5 \mathrm{~mm}$ diam. at base, $4 \mathrm{~mm}$ diam. distally; stamens not obviously arranged into discrete flowers, thecae almost globose with the pair per stamen separated by the impressed connective between elevated thecae; pores each with a heavily thickened rim, dull white; appendix base slightly wider than top of staminate flower zone, slightly curving-conoid c. $12 \mathrm{~mm}$ long, tip blunt; appendix staminodes composed of well-defined irregularly polygonal, more or less flat-topped staminodes c. $0.5 \mathrm{~mm}$ diam., white. Fruiting spathe rather loosely urceolate with conspicuously thickened walls that at fruit maturity split longitudinally, recurving to release the fruits; fruits tapering lageniform, initially green, ripening to translucent green with seeds clearly visible through the pericarp; seeds ellipsoid, testa longitudinally ridged, each enclosed by a viscous aril.

Etymology: From the Greek noun $\gamma \varepsilon \dot{\varphi} \varphi \rho \alpha-$ a bridge - devised to suggest the interstice staminodes linking the two separate fertile flower zones of the spadix.

Other material seen: MALAYSIAN BORNEO. Sarawak: Kapit Division. Belaga, km 10 towards Bakun from the Bintulu-Miri road junction, 2०50'51.7'N 11401'57.6'E, 11 Oct 2005, P.C.Boyce, Jeland ak Kisai \& Jepom ak Tisai AR-1392 (SAR); Belaga, Belaga road, $2^{\circ} 43^{\prime} 45.8^{\prime \prime} \mathrm{N} 113^{\circ} 45^{\prime} 37.1$ 'E, 12 Oct 2005, P.C. Boyce, Jeland ak Kisai \& Jepom ak Tisai AR1445 (SAR).

Notes: Initial molecular analyses suggests Schismatoglottis gephyra and several morphologically comparable Rejang basin species, of which Schismatoglottis belonis S.Y. Wong, Aisahtul \& P.C. Boyce (Figure 4G) is so far described, to be related. Furthermore, this Rejang subclade is phylogenetically distinct from the morphologically superficially similar $S$. gaesa S.Y. Wong, Aisahtul \& P.C. Boyce (Figure 4H) from Kalimantan Utara, Indonesian Borneo.

Schismatoglottis pichinensis P.C. Boyce, sp. nov. (Figures $2 \& 4 C$ ).

Diagnosis: The spadix of Schismatoglottis pichinensis somewhat resembles that of $S$. smaragdina, differing by the small flat-topped (vs large round-topped) staminodes and much smaller pistils. Vegetatively $S$. pichinensis is distinct from $S$. smaragdina by having abaxially pruinose elliptic leaf blades up to $5 \mathrm{~cm}$ wide (vs leaf blades very narrowly elongate-elliptic, up to $2 \mathrm{~cm}$ wide and emerald green on both surfaces).

Type: MALAYSIAN BORNEO. Sarawak. Serian Division, Kampung Pichin, Umon Murut, Tiab Belanting, $1^{\circ} 08^{\prime} 03.7^{\prime \prime} \mathrm{N} 110^{\circ} 27^{\prime} 00.3^{\prime \prime E}, 22$ Jun 2005, P.C. Boyce \& Jeland ak Kisai AR-1252 (Holotype: SAR).

Ecology \& distribution: Moist shaded forested Triassic-Jurassic Karst limestone between 90$250 \mathrm{~m}$ asl.

Description: Small, colony-forming mesophytic herb to c. $20 \mathrm{~cm}$ tall. Stem creeping to sprawling, mostly somewhat elongate, to c. $20 \mathrm{~cm}$ long, c. $0.5 \mathrm{~cm}$ diam., epigeal, rooting along its length, 


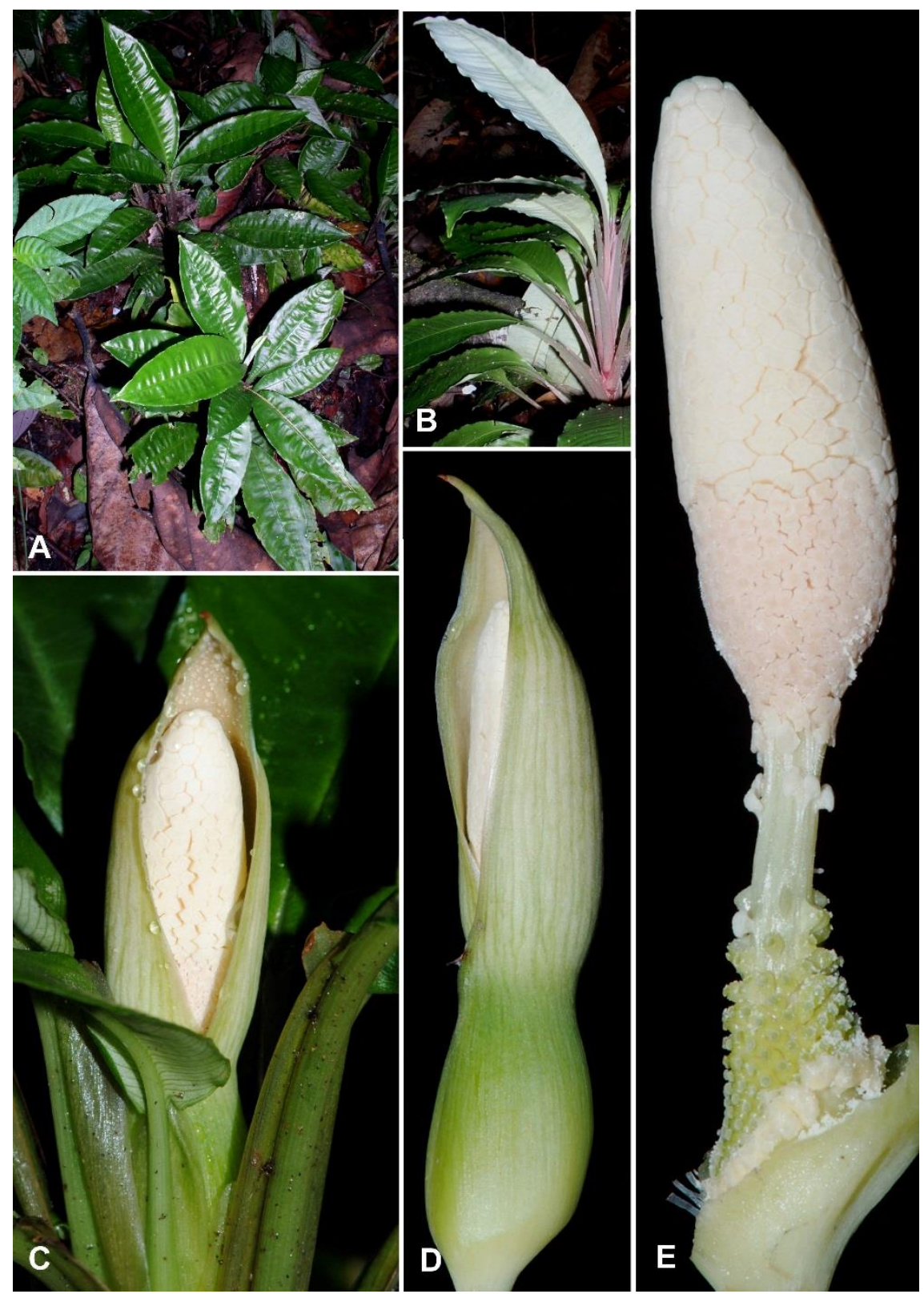

Figure 2. Schismatoglottis pichinensis P.C. Boyce, sp. nov. A. Plants in habitat. B. \& C. Inflorescence at late pistillate anthesis. D. Spadix at pistillate anthesis, spathe artificially removed. The rhomboid staminodes of the interstice and well-differentiated pale salmon pink stamens are clearly visible. E. Ripe infructescence with persistent lower spathe walls splitting and reflexing to release the ripe fruits.

occasionally branching, modules pleionanthic with older naked portions often producing hapaxanthic reiterations, internodes $0.5-1 \mathrm{~cm}$ long, pale green to pale reddish. Leaves several together along distal parts of stem and clustered at apex; petiole 8-12 cm long, sheathing in lower $1 / 3-1 / 2$, green to somewhat pale reddish, weakly longitudinally ridged, slightly D-shaped in cross- section; petiolar sheath wings fully attached to petiole, tapering, membranous, longpersistent, pale green to pale reddish; leaf blades elliptic and slightly falcate, $7-12 \mathrm{~cm}$ long $\times 2.5-$
$4 \mathrm{~cm}$ wide, base acute, apex acute and slightly acuminate for c. 5-8 mm, very glossy medium green adaxially, strikingly pruinose abaxially; midrib abaxially prominent, adaxially flush with blade; primary lateral veins 8-9 on each side, mostly alternating with lesser interprimaries, diverging at $80-100^{\circ}$, then gradually upcurved more or less throughout their length to spreading most of way across blade then abruptly upcurved, abaxially prominent in older leaves; secondary venation mostly arising from midrib, occasionally from base of primary veins; tertiary 
venation forming a conspicuous tessellate reticulum abaxially. Inflorescence solitary; peduncle to c. $2 \mathrm{~cm}$ long, not exserted from leaf bases. Spathe c. $3.5 \mathrm{~cm}$ long; lower spathe $1 \mathrm{~cm}$ long, ovoid, differentiated from limb by a constriction, inflating at pistillate anthesis, medium green; spathe limb broadly ovate, c. 1.8 $\mathrm{cm}$ long, mucronate for $2-4 \mathrm{~mm}$, pale green with darker longitudinal veins, interior faintly reddish suffused. Spadix c. $3 \mathrm{~cm}$ long, sessile; pistillate flower zone c. $6 \mathrm{~mm}$ long, narrowly conoid; pistils somewhat lax, subglobose, $0.5 \mathrm{~mm}$ diam.; stigma sessile, button-like, c. 1/2 diameter of ovary; interpistillar staminodes confined to a ring at base of pistillate flower zone, large (c. 2 $\mathrm{mm}$ wide) with a wide top centrally impressed, waxy white; sterile interstice attenuate, partly to completed naked, 3-4 mm long, green, at base an irregular whorl of abortive pistils, distally these scattered and resembling tiny flat-capped mushrooms, finally a loose group of abortive stamens; staminate flower zone obconoid, $6 \mathrm{~mm}$ long, $1.5 \mathrm{~mm}$ diam. at base, $4 \mathrm{~mm}$ diam. distally; stamens crowded, dumbbell-shaped, more or less truncate with connective almost flat between thecae; pores each with a heavily flanged rim, dirty white; appendix conic-ellipsoid c. $1 \mathrm{~cm}$ long, tip blunt; appendix staminodes irregularly polygonal, more or less flat-topped staminodes c. $0.75 \mathrm{~mm}$ diam., white. Fruiting spathe shortpeduncled, erect, urceolate, c. $1 \mathrm{~cm}$ long; fruits and seeds not observed.

Etymology: The trivial epithet is from the Type locality plus the suffix -ensis, indicating 'from'.

Other material seen: MALAYSIAN BORNEO. Sarawak: Serian Division. Kampung Pichin, Sungai Bombo, 25 Nov 2004,P.C. Boyce \& Simon Kutuh ak Paru AR-763 (SAR) \& 5 Dec 2004 P.C. Boyce \& Simon Kutuh ak Paru AR852 (SAR); Kampung Pichin, Susih, 25 Nov 2004, P.C. Boyce \& Simon Kutuh ak Paru AR769 (SAR); Kampung Pichin, Gunung Kedadum, Sugun Kerang, 25 Nov 2004, P.C. Boyce \& Simon Kutuh ak Paru AR-778 (SAR); Kampung Pichin, Darud Sipukam, 25 Mar 2005, P.C. Boyce \& Simon Kutuh ak Paru AR-1123 (SAR); Kampung Pichin, Tubih, Tahang Sipukam, $1^{\circ} 07^{\prime} 16.6^{\prime \prime} \mathrm{N} 110^{\circ} 26^{\prime} 51.2^{\prime \prime} \mathrm{E}, 26 \mathrm{Jul}$ 2005, P.C. Boyce et al. AR-1308 (SAR); Kampung Pichin, Umon Murut, Tiab Belanting, $1^{\circ} 08^{\prime} 03.7^{\prime \prime N ~} 110^{\circ} 27^{\prime} 00.3 " \mathrm{E}, 15$ Mar 2011, P.C. Boyce AR-3529 (SAR).
Notes: Schismatoglottis pichinensis is remarkable for the leaf blades abaxially pruinose. Rather similar plants are known from the environs Bau (Sarawak: Kuching) where they occur on younger and rather drier Cretaceous limestones. These Bau plants have yet to flower to confirm identity.

The spadix of $S$. pichinensis is reminiscent of that of the Rejang Basin S. smaragdina S.Y. Wong, Aisahtul \& P.C. Boyce (Figure 4D) but the plants are vegetatively quite dissimilar.

Schismatoglottis puncakborneensis P.C. Boyce, sp. nov. (Figures $3 \& 4$ A).

Diagnosis: Schismatoglottis puncakborneensis approaches Schismatoglottis retinervia in overall spadix morphology, differing by the lower spathe becoming translucent during anthesis (vs lower spathe remaining opaque throughout anthesis), the cream (not green) pistils, and by the interstice bearing a few staminate-flower like staminodes (vs interstice wholly naked). In all examined plants of $S$. puncakborneensis the petioles are glabrous, as opposed to puberulent as in $S$. retinervia.

Type: MALAYSIAN BORNEO. Sarawak. Kuching Division, Padawan, Puncak Borneo, trail Hornbill Resort golf course maintenance kampong, $1^{\circ} 07^{\prime} 35.1^{\prime \prime N} 110^{\circ} 13 ' 28.8^{\prime \prime E}, 30$ Sep 2003, P.C. Boyce \& Jeland ak Kisai AR-91 (Holotype: SAR; isotype SAR - alcohol preserved).

Ecology \& distribution: Terrestrial in shaded moist upper hill forest on Paleogene sandstones, often near streams, between 880-970 m asl.

Description: Small, solitary or more usually colony-forming mesophytic herb to c. $15 \mathrm{~cm}$ tall. Stem creeping to somewhat elongate, to c. $15 \mathrm{~cm}$ long, c. $0.8 \mathrm{~cm}$ diam., epigeal, rooting along its length, internodes c. $1 \mathrm{~cm}$ long, pale green. Leaves mostly clustered at apex of stems petiole $8-12 \mathrm{~cm}$ long, sheathing in lower $1 / 3-1 / 2$, green, weakly longitudinally ridged, slightly D-shaped in cross-section; petiolar sheath wings fully attached to petiole, tapering, membranous, longpersistent, pale green; leaf blades glossy medium green adaxially, paler abaxially, elliptic and often slightly falcate, $7-12 \mathrm{~cm}$ long $\times 2.5-4 \mathrm{~cm}$ wide, base acute, apex acute and slightly acuminate for c. 5-8 $\mathrm{mm}$; midrib abaxially prominent, often 


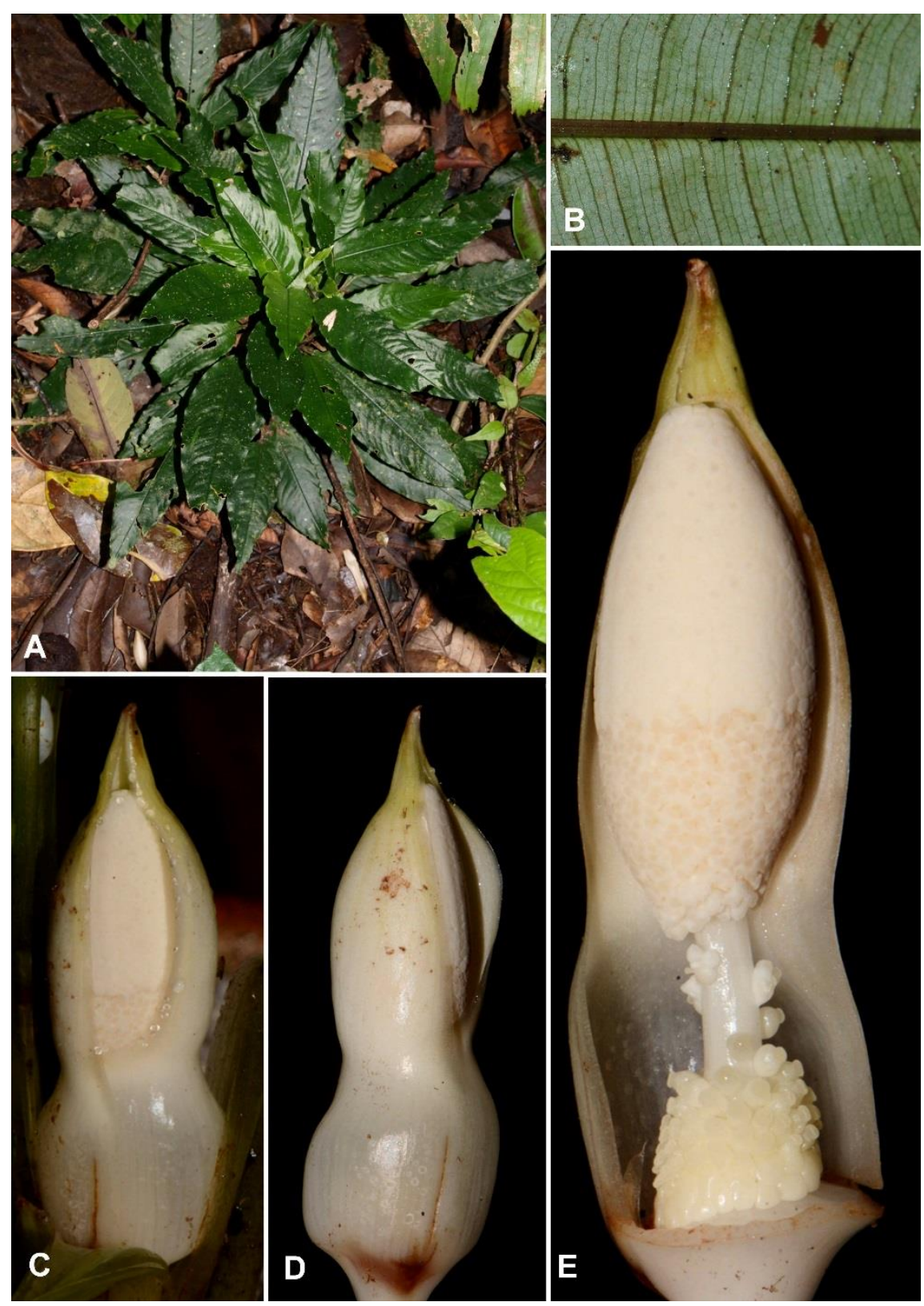

Figure 3. Schismatoglottis puncakborneensis P.C. Boyce, sp. nov. A. Plants in habitat. B. Leaf blade, abaxial view, showing the typical venation of species of the Schismatoglottis Patentinervia Clade. C \& D. Inflorescence at late anthesis. Note that the spathe limb hardly opens. D. Spadix at pistillate anthesis, spathe artificially removed. The staminate flower-like staminodes of the interstice are clearly visible.

rather reddish brown, adaxially flush with blade; primary lateral veins c 10 on each side, alternating with slightly lesser interprimaries, diverging at $80-100^{\circ}$, then gradually upcurved more or less throughout their length to spreading most of way across blade then abruptly upcurved, abaxially prominent in older leaves; secondary venation mostly arising from midrib, occasionally from base of primary veins; tertiary venation forming a conspicuous tessellate reticulum abaxially. Inflorescence solitary; peduncle to c. $2.5 \mathrm{~cm}$ long, usually only slightly exserted from leaf bases. Spathe $2.5 \mathrm{~cm}$ long; lower spathe $1 \mathrm{~cm}$ long, ovoid, differentiated from limb by a constriction, inflating markedly at pistillate anthesis and becoming translucent whitish green; spathe limb broadly ovate, c. 1.5 $\mathrm{cm}$ long, stoutly mucronate for c. $3 \mathrm{~mm}$, pale green, upper part darker. Spadix c. $2.2 \mathrm{~cm}$ long, sessile; pistillate flower zone c. $5 \mathrm{~mm}$ long, stoutly conoid; pistils very dense, stoutly lageniform, c $0.7 \mathrm{~mm}$ diam., creamy; stigma short-stipitate, button-like, about as wide as ovary; interpistillar staminodes confined to a 

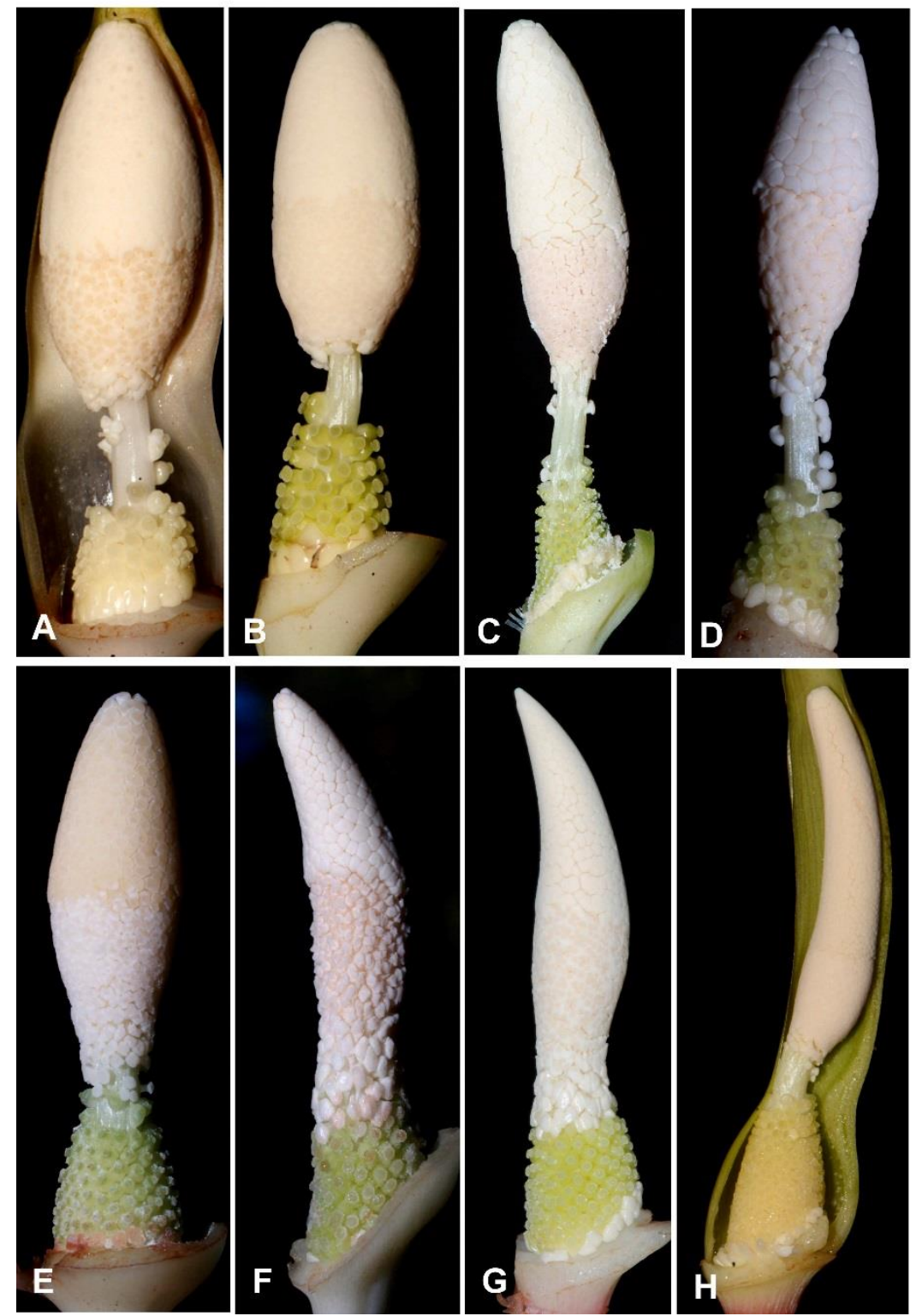

Figure 4. Spadices of eight species of Schismatoglottis Patentinervia Clade compared. A. Schismatoglottis puncakborneensis P.C. Boyce, sp. nov. B. Schismatoglottis retinervia Furtado. C. Schismatoglottis pichinensis P.C. Boyce, sp. nov. D. Schismatoglottis smaragdina S.Y. Wong, Aisahtul \& P.C. Boyce. E. Schismatoglottis pectinervia A. Hay. F. Schismatoglottis gephyra P.C. Boyce, sp. nov. G. Schismatoglottis belonis S.Y. Wong, Aisahtul \& P.C. Boyce. H. Schismatoglottis gaesa S.Y. Wong, Aisahtul \& P.C. Boyce. Note that the ninth described species, S. patentinervia Engl. is as yet not known fertile (Wong et al., 2017).

ring at base of pistillate flower zone, c. $1 \mathrm{~mm}$ wide, top flattened to slightly convex, glossy pale cream; sterile interstice attenuate, naked, 3$4 \mathrm{~mm}$ long, whitish, with a few scattered cream staminate flower-like staminodes; staminate flower zone obconoid, $6 \mathrm{~mm}$ long, $1.5 \mathrm{~mm}$ diam. at base, $4 \mathrm{~mm}$ diam. distally; stamens very crowded, dumbbell-shaped, more or less truncate with connective very slightly mounded between thecae; pores each with a heavily flanged rim, dark cream; appendix conic- ellipsoid $5 \mathrm{~mm}$ long and wide at base, tip blunt; appendix staminodes irregularly polygonal, hardly differentiated, more or less flat-topped staminodes c. $0.5 \mathrm{~mm}$ diam., white. Fruiting spathe, fruits, and seeds not observed.

Etymology: Contrived from Latin, -ensis, meaning 'from', and the Type locality of Borneo Heights - in Malay Puncak ("Punchak") Borneo - hence the Schismatoglottis from Borneo Heights. 
Other material seen: MALAYSIAN BORNEO. Sarawak: Kuching Division. Padawan, Puncak Borneo, Jungle Trail, $1^{\circ} 07^{\prime} 36.3^{\prime \prime N} 110^{\circ} 12^{\prime} 58.7^{\prime \prime E}, 15$ Sep 2014, Wong Sin Yeng \& P.C. Boyce AR-459 (SAR - alcohol preserved).

Notes: Schismatoglottis retinervia Furtado (Figure 4B), another species from this altitude, is remarkably similar in spadix morphology to $S$. puncakborneensis (compare Figures 4A \& 4B). Molecular evidence also supports a relationship between these and several other currently undescribed species with similar spadix morphology and also favouring habitats at this altitude.

The lower spathe becoming translucent during anthesis in Schismatoglottis puncakborneensis is reminiscent of the not closely allied S. cameralucida P.C. Boyce \& S.Y. Wong (Boyce \& Wong, 2014).

\section{ACKNOWLEDGEMENTS}

Fieldwork associated with this research was most recently under Sarawak Forestry Department Permission to Conduct Research on Biological Resources Permit No. NPW.907.4.4 (JLD.14)-159 and Park Permit No. WL82/2017. The collaboration and support of the Sarawak Forestry Department, the Forest Research Centre (Kuching), and the Sarawak Biodiversity Centre are gratefully acknowledged.

\section{REFERENCES}

Boyce, P.C. \& Wong, S.Y. (2014) Studies on Schismatoglottideae (Araceae) of Borneo XXXVII - Three enigmatic new species of Schismatoglottis from the "Heart of Borneo". Aroideana, 37E(1): 17-28.

Boyce, P.C. \& Wong, S.Y. (2015). Compendium genera Aracearum Malesianum. Aroideana, 38: 40-77.

Low, S.L. (2016). Phylogeny and aspects of reproductive biology of Aridarum (Schismatoglottideae: Araceae) (Ph.D. Thesis). Universiti Malaysia Sarawak, Malaysia.

Low S.L., Wong, S.Y. \& Boyce, P.C. (in press). Generic redelimitation in Schismatoglottideae (Araceae) including recognition of 11 new and five resurrected genera. Phytotaxa.

Tate, R.B. (2001). The geology of Borneo island CDROM. Kuala Lumpur: Persatuan Geologi Malaysia / Geological Society of Malaysia.

Wong, S.Y., Low S.L. \& Boyce, P.C. (2016). Studies on Schismatoglottideae (Araceae) of Borneo LVI - Two new species of Schismatoglottis for the Nervosa Grade. Willdenowia, 46(3): 291-298.

Wong, S.Y., Aisahtul binti Wardi \& Boyce, P.C. (2017). Studies on Schismatoglottideae (Araceae) of Borneo LX: Preliminary notes on the Schismatoglottis Patentinervia Clade, including description of three new species. Aroideana, 40(1): 4-28. 